\title{
Epithelial rests of Malassez in experimental animals at different ages
}

\author{
Gisela E. Pulitano - Manisagian, Patricia M. Mandalunis \\ Universidad de Buenos Aires, Facultad de Odontología, Cátedra de Histología y Embriología, Buenos Aires, \\ Argentina.
}

\begin{abstract}
Epithelial rests of Malassez (ERMs) are fragments of Hertwig's sheath in the periodontal ligament. There is extensive knowledge of their role in the etiology of pathological processes and current evidence links them to maintenance of periodontal homeostasis. The aim of this study was to assess the behavior of ERMs with relation to the changes in periodontal tissues during growth in an experimental model with Wistar rats. Mesiodistal sections were made of the first lower molars from Wistar rats aged 1 month $(n=7), 3$ months $(n=7)$ and 5 months $(n=6)$. Sections were stained with $H \& E$ to evaluate number of ERMs/ $\mathrm{mm}$, sizelarea of ERMs ( $\mu \mathrm{m} 2)$, height of periodontal ligament (PL.h) $(\mu \mathrm{m})$, area of cement in the furcation zone (C.Ar) ( $\mu \mathrm{m} 2)$ and bone area related to the ERM zone (BAr/TAr)(\%). Posthoc Bonferroni and ANOVA were applied for statistical analysis of results. Number of ERMs $/ \mathrm{mm}$ declined significantly with age (1m: 4.34 $\pm 1.51,3 m: 1.48 \pm 0.89,5 m: 0.27 \pm 0.50, p \leq 0.05$ ), and there was great variability in size. There was significant
\end{abstract}

increase in C.Ar (1m: $3418.96 \pm 905.88,3 m: 19365.76 \pm$ 5500.52, 5m: $32182.76 \pm 7114.51, p \leq 0.05)$ and interradicular (BAr/TAr) (1m: 25.26 $\pm 2.37,3 m: 44.70 \pm 3.95,5 m: 46.81 \pm$ 7.80, $p \leq 0.05: 1$ vs 3, 1 vs 5). There was significant decline in PLh at 5 months (1m: $141.42 \pm 29.25,3 \mathrm{~m}: 162.06 \pm 28.21$, 5m: $124.72 \pm 18.67, p \leq 0.05: 1$ vs. 3, 3 vs. 5). The decline in number of ERMs as animal age increases may be related to the significant increase in C.Ar and reduction in PL.h. It remains to ascertain its relationship with the increase observed in BAr/ TAr. Further studies are needed to learn more about the role of ERMs and their relationship with periodontal tissues when confronted with different normal and pathological stimuli.

Received: January 2021; Accepted: March 2021.

Keywords: epithelial rests of Malassez - periodontal ligament alveolar bone - periodontium - histomorphometry.

\section{Restos epiteliales de Malassez en animales experimentales a diferentes edades}

\begin{abstract}
RESUMEN
Los restos epiteliales de Malassez (ERMs) son fragmentos de la vaina de Hertwig, en el ligamento periodontal. Se conoce extensamente su rol en la etiología de procesos patológicos y actualmente las evidencias los vinculan al mantenimiento de la homeostasis periodontal. El objetivo del presente trabajo fue evaluar el comportamiento de los ERMs en relación a los cambios de los tejidos periodontales durante el crecimiento en un modelo experimental de ratas Wistar. Se obtuvieron cortes mesio-distales del ler molar inferior de ratas Wistar de 1 mes $(n=7), 3$ meses $(n=7)$ y 5 meses $(n=6)$ de edad. En cortes coloreados con H\&E, se evalúo: $N^{o}$ de ERMs/mm, tamaño/ área de ERMs ( $\mu \mathrm{m} 2)$, altura del ligamento periodontal (PL.h) $(\mu \mathrm{m})$, área de cemento en la zona de furcación (C.Ar) ( $\mu \mathrm{m} 2)$ y área del hueso relacionado con la zona de los ERMs (BAr/TAr) (\%). Los resultados se analizaron estadísticamente mediante ANOVA y Bonferroni post-hoc. El $N^{o}$ de ERMs/mm disminuyó significativamente con la edad (1m: 4.34 $\pm 1.51,3 m: 1.48 \pm 0.89$,

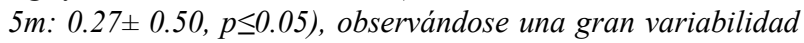

de tamaño. Se observó un aumento significativo del C.Ar (1m: $3418.96 \pm 905.88,3 m: 19365.76 \pm 5500.52,5 m: 32182.76 \pm$ 7114.51, $p \leq 0.05)$ y del (BAr/TAr). interradicular (1m: 25.26 $\pm 2.37,3 m: 44.70 \pm 3.95,5 m: 46.81 \pm 7.80, p \leq 0.05: 1$ vs 3 , 1 vs 5). Además, se halló una disminución significativa en PLh a los 5 meses $(1 \mathrm{~m}: 141.42 \pm 29.25,3 \mathrm{~m}: 162.06 \pm 28.21$, $5 m: 124.72 \pm 18.67, p \leq 0.05: 1$ vs 3, 3 vs 5). La disminución hallada del número de ERMs conforme aumenta la edad del animal podría vincularse con el aumento significativo del C.Ar y la reducción del PL.h. Resta por dilucidar su relación con el aumento de BAr/TAr. observado. Se requieren más estudios para profundizar sobre el rol de los ERMs y su relación con los tejidos periodontales ante distintos estímulos normales $y$ patológicos.

Palabras clave: restos epiteliales de Malassez - ligamento periodontal - hueso alveolar - periodontium - histomorfometría. 


\section{INTRODUCTION}

The insertion periodontium components that make up the topographic and functional unit are root cementum, periodontal ligament and alveolar bone. These structures evolve in an interrelated, coordinated manner over the life of the tooth, adapting continuously to changes that take place in the mouth. The periodontal ligament is located between the cementum and the alveolar bone. It is a fibrous connective tissue comprising a wide variety of cells: fibroblasts, osteoblasts, cementoblasts, osteoclasts, macrophages, mastocytes, undifferentiated ectomesenchymal cells and epithelial rests of Malassez (ERMs). Cell activity is mediated by several signaling factors that regulate the complex growth and regeneration machinery of periodontal structures $^{1}$. After root formation, remnants of Hertwig's sheath persist as ERMs throughout the life of the tooth ${ }^{2,3}$. Although their etiological role in the formation of odontogenic tumors and cysts is widely known, ERMs are currently a subject of interest as structures that take part in the histophysiology of the periodontal ligament. Histologically, ERMs are identified as small groups of epithelial cells within the periodontal ligament, in close contact with the cementum surface, becoming increasingly distant from the cementum surface towards the coronal third of the root ${ }^{4}$. Oblique sections of the periodontal ligament have shown ERMs to form part of mesh around the root ${ }^{5}$. ERMs have also been shown to have an irregular nucleus with dense heterochromatin and a small, scarcely distinguishable peripheral halo of cytoplasm $^{6}$. ERM ultrastructure in sections of rat periodontal ligament is similar to that in humans and other animals ${ }^{7,8}$. A basal lamina separates the ERM cell islands from the connective tissue ${ }^{9}$, and there are tight junctions between them and hemidesmosomes, and tonofilaments within the cytoplasm. ERMs can produce different proteins and macromolecules, including cytokeratins ${ }^{10,11}$ and neuropeptides ${ }^{12}$. The expression of CK 17 could be a marker used for identification ${ }^{13}$. Other studies ${ }^{14,15}$ also report the expression of cell surface proteins such as epidermal growth factor receptors. It has been observed that proteins typical of the enamel matrix such as amelogenin and ameloblastin are expressed from samples of human periodontal ligament ${ }^{16,17}$. It has been suggested that these two proteins may act as growth factors and participate in adhesiveness, proliferation, migration and differentiation of periodontal ligament fibroblasts ${ }^{18,19}$. Moreover, it has been found that disruption of periodontal integrity induced early expression of APINA (another protein of the enamel matrix), forming part of a cascade of events possibly leading to the activation of the ERMs during periodontal healing and regeneration ${ }^{20}$.

Despite the ectodermal origin and epithelial nature of these cell groups, they can synthesize components that are frequently associated to cells of mesenchymal origin, such as glycosaminoglycans, hyaluronic acid, dermatan sulfate and chondroitin sulfate ${ }^{21}$, as well as osteopontin (OPN), bone sialoprotein (BSP) and osteoprotegerin (OPG) $)^{4,22}$. They can also degrade collagen by synthesis of collagenases and proteinases $^{23,24}$. It has therefore been suggested that they may contribute to periodontal regeneration by synthesizing a series of proteins related to the cementum and the bone tissues ${ }^{25}$. Current scientific evidence suggests that the possible role of ERMs in adult periodontal ligament is related to maintaining homeostasis of the periodontal space, thereby preventing anchylosis, inhibiting root resorption and contributing to cementum repair ${ }^{26,27}$.

In previous papers, our group has reported that in an experimental periodontitis model, ERMs exhibited cell hypertrophy when there was root resorption $^{28}$. Other authors have evaluated ERM cell response to in vivo mechanical stimuli, observing cell proliferation and hypertrophy ${ }^{29}$. Regarding this point, our group studied ERMs in an experimental model of root resorption mediated by orthodontic forces in rats, finding no significant morphological change that would highlight their role in root resorption induced by orthodontic forces ${ }^{30}$. Other studies have described the expression of several proteins $\mathrm{s}^{27,31}$ that may contribute to the maintenance of cementogenesis and osteogenesis. Among these proteins, the expression of HSP 70 (Heat Shock Protein) by ERMs may provide protection against different forms of attack, including oxidizing agents, inflammation, hypoxia, hyperthermia and mechanical stimuli such as orthodontic forces ${ }^{32}$.

The aim of this study was to assess the behavior of periodontal tissues with relation to ERMs in healthy Wistar rats at different ages.

\section{MATERIALS AND METHODS}

We used 20 healthy male Wistar rats aged 1 month $(n=7), 3$ months $(n=7)$ and 5 months $(n=6)$. All 
animals had "ad libitum" access to balanced feed and water. They were housed in galvanized wire cages containing not more than 5 animals each, with temperature $21{ }^{\circ} \mathrm{C}$ to $24{ }^{\circ} \mathrm{C}$; Humidity $52 \%$ to $56 \%$; light/dark cycles: 12 hours/12 hours.

The experimental protocol was approved by the Ethics Committee of the School of Dentistry 012/2016 CICUAL-ODONTO-FOUBA of Buenos Aires, Argentina, and is in keeping with the National Institutes of Health Guidelines for the Care and Use of Laboratory Animals.

\section{Histology and Histomorphometry}

Following euthanasia at the relevant experimental times, lower jaws were extracted and fixed in $10 \%$ buffered formalin ( $\mathrm{pH}$ 7.4). Samples were desiccated and decalcified in 10\% EDTA solution, $\mathrm{pH} 7.0$, for 25 days.

The section of each hemimandible corresponding to the three lower molars was embedded in paraffin to prepare mesiodistal histological sections of the lower first molar. Sections were stained with hematoxylineosin. The section with best orientation from each hemimandible, showing mesial and distal roots up to the apices, was selected.

The following parameters were evaluated at the furcation zone:

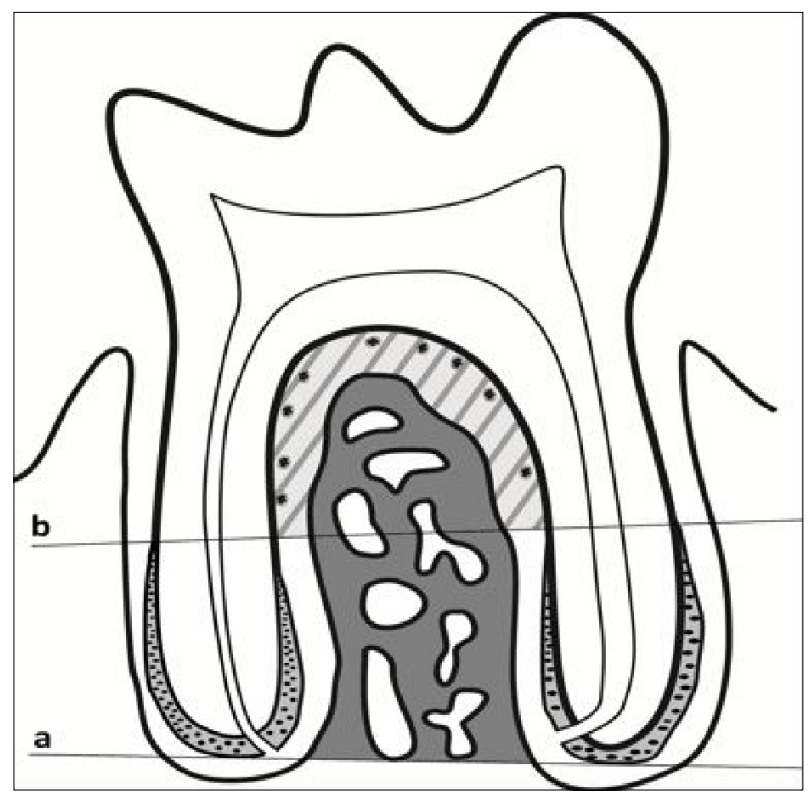

Fig. 1: Diagram of rat molar in situ. Line " $a$ " joins the two apices and limits the total interradicular space in which B.Ar/T.Ar (\%) was evaluated. Line " $b$ ", drawn at the beginning of the cellular cementum, limits the periodontal area (shaded and lined) where ERMs were evaluated.
- Number of ERMs/mm: number of ERMs in the periodontal ligament in the perimeter limited by the beginning of cellular cementum, expressed with relation to root surface (Fig. 1).

- Size/Area of ERMs $\left(\mu m^{2}\right)$ : Area of ERMs

- Height of periodontal ligament (PL.h) $(\boldsymbol{\mu m})$ : average of five equidistant linear measurements between the cementum surface of the furcation zone and the beginning of the bone tissue (Fig. 2).

- Area of cementum in the furcation zone: $C . A r$ $\left(\mu m^{2}\right)$ : measurement of the area of cementum in the zone limited by the projection of two lines, on the mesial and distal root surfaces (Fig. 3).

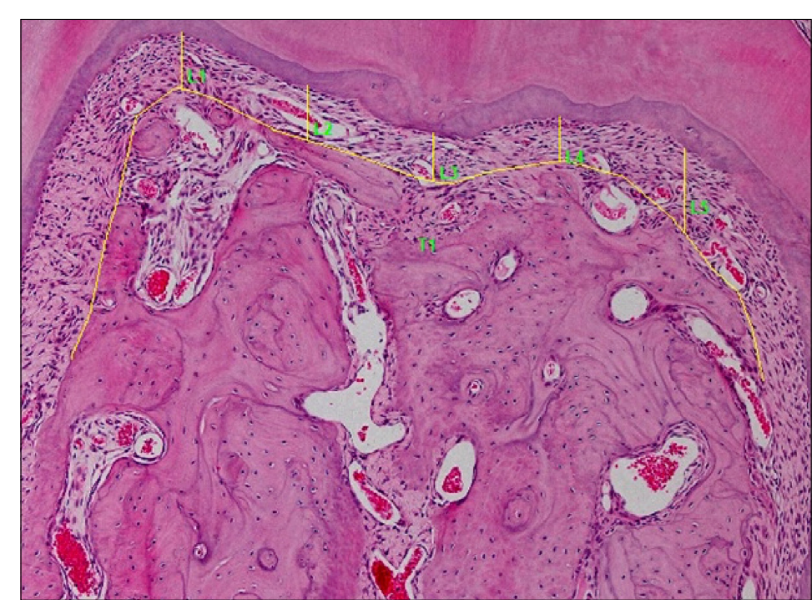

Fig. 2: Microphotograph of a mesiodistal section of lower molar showing the 5 lines used for measuring height of the periodontal ligament. H\&E. $100 X$.

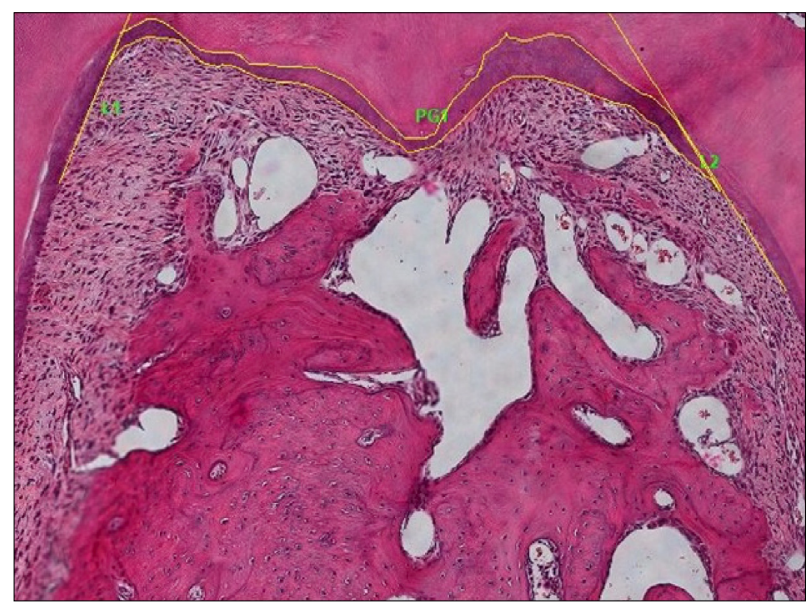

Fig. 3: Microphotograph of a mesiodistal section of lower molar. The two lines (L1 and L2) projected on the cementum surface demarcate the furcation zone where cementum area (C.Ar) was evaluated. H\&E. $100 X$. 
- Bone area B.Ar/T.Ar: Area of trabecular bone tissue in the zone selected for measuring ERMs, expressed as percentage of total area of interradicular bone (Fig. 1).

Number of ERMs was counted directly under 100x magnification with a Bausch \& Lomb microscope. The rest of the histomorphometric measurements were taken using 100X digital microphotographs taken with a Nikon Eclipse photomicroscope and Image Pro-Plus Software.

Statistical analysis was performed with post-hoc Bonferroni and ANOVA, considering significance at $\mathrm{p}<0.05$.

\section{RESULTS}

The results show that number of ERMs $/ \mathrm{mm}$ declined significantly with age of animals, with major variability and high standard deviations in size of ERMs found in each group. This variability is reflected by the high standard deviations obtained for this parameter. In the 5-month-old group, ERMs were only observed in 3 of the 6 animals. Moreover, there was a significant increase in cementum area and bone area in the interradicular zone and a significant decrease in the height of the periodontal ligament in the 5-month-old group in relation to the other groups (Table 1 and Figs 4 and 5). Interestingly, we observed nuclei compatible with ERMs associated with and even embedded in the cementum matrix in the furcation zone (Fig. 6).

\begin{tabular}{|c|c|c|c|}
\hline & 1 month & 3 months & 5 months \\
\hline Number of ERMs/mm & $\begin{array}{c}4.34 \pm 1.51 \\
\text { a }\end{array}$ & $\begin{array}{c}1.48 \pm 0.89 \\
\text { b }\end{array}$ & $\begin{array}{c}0.27 \pm 0.50 \\
\text { c }\end{array}$ \\
\hline Size/Area of ERMs $\left(\mu \mathrm{m}^{2}\right)$ & $\begin{array}{c}213.61 \pm 61.84 \\
\text { a }\end{array}$ & $\begin{array}{c}431.91 \pm 180.21 \\
\text { b }\end{array}$ & $\begin{array}{c}203.43 \pm 82.23 \\
\text { a }\end{array}$ \\
\hline $\begin{array}{l}\text { Height of periodontal ligament (PL.h) } \\
\qquad(\mu \mathrm{m})\end{array}$ & $\begin{array}{c}141.42 \pm 29.25 \\
\mathbf{a} \mathbf{b}\end{array}$ & $\begin{array}{c}162.06 \pm 28.21 \\
\text { b }\end{array}$ & $\begin{array}{c}124.72 \pm 18.67 \\
\text { a }\end{array}$ \\
\hline $\begin{array}{l}\text { Area of cementum at furcation (C.Ar) } \\
\qquad\left(\mu \mathrm{m}^{2}\right)\end{array}$ & $\begin{array}{c}3418.96 \pm 905.88 \\
\text { a }\end{array}$ & $\begin{array}{c}19365.76 \pm 5500.52 \\
\text { b }\end{array}$ & $\begin{array}{c}32182.76 \pm 7114.51 \\
\text { c }\end{array}$ \\
\hline Bone area (B.Ar/T.Ar) (\%) & $\begin{array}{c}25.26 \pm 2.37 \\
\text { a }\end{array}$ & $\begin{array}{c}44.70 \pm 3.95 \\
\text { b }\end{array}$ & $\begin{array}{c}46.81 \pm 7.80 \\
\text { b }\end{array}$ \\
\hline
\end{tabular}

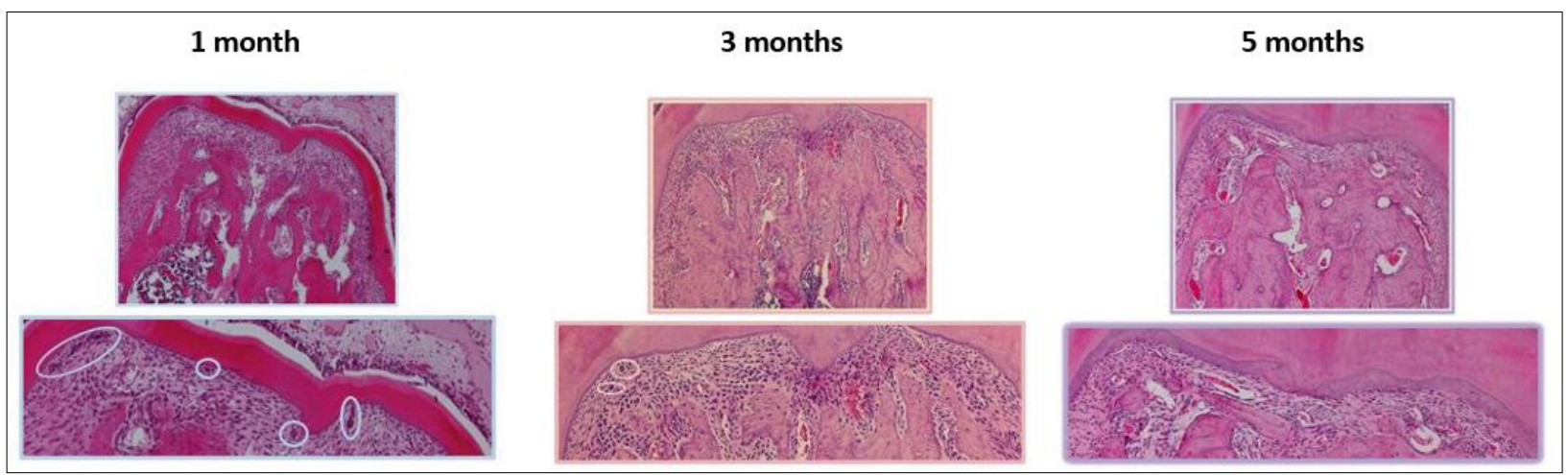

Fig. 4: Microphotographs of mesiodistal sections of lower molar of Wistar rats aged 1, 3 and 5 months, showing the decline in number of ERMs, the increase in cementum area at the level of the furcation and the reduction of the periodontal space as animal chronological age increases. $H \& E .40$ and $100 X$. 


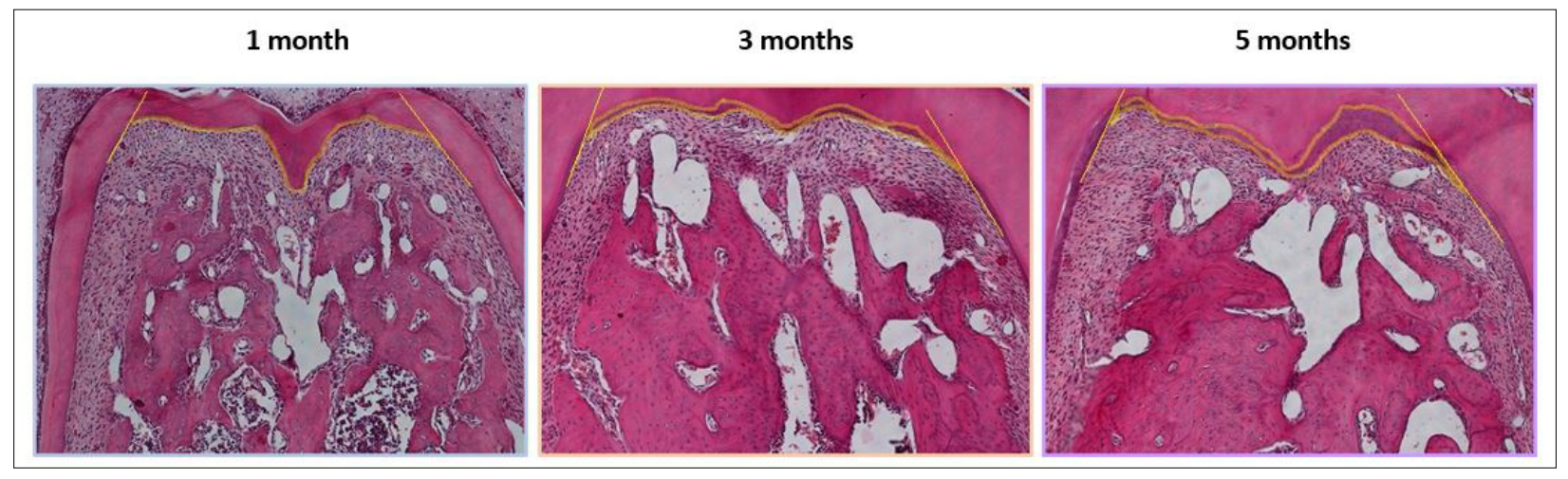

Fig. 5: Microphotographs of mesiodistal sections of lower molar in Wistar rats aged 1, 3 and 5 months, showing delimitation established for evaluating the cementum area in the furcation zone in the 3 age groups. H\&E.100X.

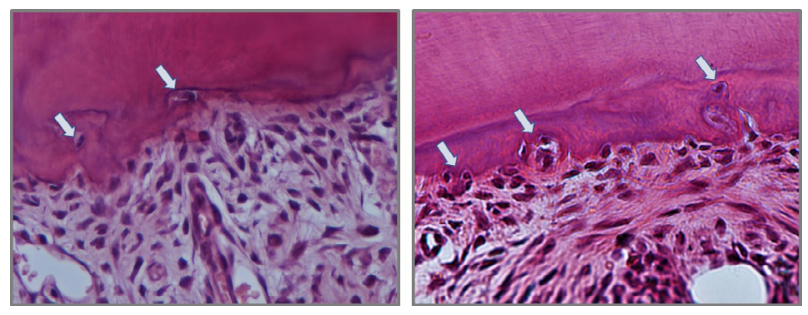

Fig. 6: Microphotographs of mesiodistal sections of lower molar in Wistar rat aged 5 months, showing cell nuclei compatible with ERMs embedded in the cementum (arrows). $H \& E .40 X$.

\section{DISCUSSION}

The results of this study show that the number of ERMs of lower molars in Wistar rats declines significantly as animal chronological age increases, and that there is major variability in size. The decline in number of ERMs was accompanied by a significant increase in interradicular cementum area at the level of the furcation and the interradicular bone area, entailing a reduction in height of the periodontal ligament when the animals were 5 months old.

The decline observed in number of ERMs with increase in age agrees with different papers published since 1950 . Wentz et al. ${ }^{33}$ suggests that the decline in number of ERMs with age may be because they degenerate and then become calcified. Studies on human ERMs have also reported that they decline as age increases, and studies on older people report the onset of ERM calcification, which persist as cementum-like structures/cementicles ${ }^{34}$. A study by Gonçalves et al. ${ }^{35}$ suggests that such decline may be partly due to cell apoptosis. In our study, the decline with age was accompanied by, and probably related to, an increase in the cementum area and interradicular bone volume and the consequent reduction in the height of the periodontal ligament.
Sims et al. ${ }^{36}$ also reports a reduction in the thickness of the periodontal space as age increased in mice. It is important to note that although our study did not find isolated partial calcifications in the periodontal ligament, it did find nuclei of cells compatible with possible ERMs embedded in the cementum associated to the interradicular space. The hypothesis that the nuclei observed in the radicular cementum matrix may have originated from nearby ERMs is also supported by the well-known fact that the topographic zone of the furcation and radicular cervical third is not characterized by presenting cellular cementum.

Hasegawa et al. ${ }^{37}$ showed that during cementum repair, ERMs express osteopontin and ameloblastin, suggesting that they may be involved in cementum repair. More recent findings suggest that within the ERMs, there is a cell population with properties similar to those of undifferentiated mesenchymal cells, which, under the right stimulus, can differentiate into cells capable of synthesizing mineralized matrices in a particular microenvironment ${ }^{38}$.

It has been more than twenty years since enamel matrix derivatives were introduced in clinical periodontics for use in regenerative therapies. Nevertheless, further research is still needed for better characterization of their effects on the behavior of different tissues and on the different cells $^{39}$. In this context, it is worth noting that ERMs can express proteins typical of the enamel matrix, such as amelogenin and ameloblastin ${ }^{16}$. These proteins may have a strong effect on cell activity of the insertion periodontum ${ }^{18,19}$. Considering that ERMs may be a natural source of these proteins within the periodontal ligament itself, it is essential to continue learning about the behavior of ERMs in different contexts and under different stimuli. 
The current study also found an increase in interradicular bone volume as chronological age increases, in agreement with other studies conducted by our group ${ }^{40}$. This finding poses a question that is yet unanswered, regarding whether there is any association between the increase in bone volume found and the behavior and/or presence of ERMs in the periodontal ligament. In further studies we will endeavor to ascertain whether there are mechanisms that operate in said association and how they work.

\section{ACKNOWLEDGMENTS}

Special thanks to Marianela Lewicki, DVM and Milton Nervegna, DDS, for their generous cooperation with this study. We also thank Mariela Lacave, Ivana Sánchez Rojas and Paula Rocha, HTec. for their excellent technical assistance.

\section{DECLARATION OF CONFLICTING INTERESTS}

The authors declared no potential conflicts of interest with respect to the research, authorship, and/or publication of this article.

\section{REFERENCES}

1. Benatti BB, Silvério KG, Casati MZ, Sallum EA, Nociti $\mathrm{NH}$ Jr. Physiological features of periodontal regeneration and approaches for periodontal tissue engineering utilizing periodontal ligament cells. J Biosci Bioeng 2007;103:1-6.

2. Spouge JD. Rests of Malassez and chronic marginal periodontal disease. J Can Dent Assoc 1980;46:712-716.

3. Thurley DC. Development, growth and eruption of permanent incisor teeth in Romney sheep. Res Vet Sci 1985;39:127-138.

4. Rincon JC, Young WG, Bartold PM. The epithelial cell rests of Malassez- arol in periodontal regeneration? J Periodontal Res 2006; 41:245-252.

5. Spouge JD. The rests of Malassez and chronic marginal periodontitis. J Clin Periodontol 1984; 11:340-347.

6. Inove T, Enokiya Y, Hashimoto S, Fukumashi K, Shimono M. Homeostatic factors in periodontal ligament after wound healing. Effects of Malassez's epithelial rests. Jpn J Oral Biol 1993; 37:58-69.

7. Hamamoto Y, Nakajima T, Ozawa H. Ultrastructural and histochemical study on the mor-phogenesis of epithelial rests of Malassez. Arch Histol Cytol 1989;52:61-70.

8. Brice GL, Sampson WJ, Sims MR. An ultrastructural evaluation of the relationship between epithelial rests of Malassez and orthodontic root resorption and repair in man. Aust Orthod J 1991;12:90-94.

9. Valderhaug JP, Nylen MU. Function of epithelial rests as suggested by their ultrastructure. J Periodont Res 1966;1:69-78.

10. Gao Z, Mackenzie IC, Williams DM, Cruchley AT, Leigh I, Lane EB. Patterns of keratin-expression in rests of Malassez and periapical lesions. J Oral Pathol 1988;17:178-185.

11. Peters BH, Peters JM, Kuhn C, Zoller J, Franke WW. Maintenance of cell-typespecifi cytoskeletal character in

\section{CONCLUSIONS}

Further studies are needed to learn more about the role of ERMs and their association with the cementum, periodontal ligament and bone tissue, both in health and in situations requiring periodontal repair and/or regeneration mechanisms. In addition to providing insight regarding the biology of ERMs, this study contributes to a better characterization of an animal model that is extensively used in research on different aspects of oral pathology.

\section{FUNDING}

This work was supported by a grant from Universidad de Buenos Aires, UBACyT Program \# 20020160100034BA

\section{CORRESPONDENCE}

Od. Gisela Pulitano Manisagian.

Cátedra de Histología y Embriología, Facultad de Odontología Marcelo T. de Alvear 2142, $1^{\circ} \mathrm{A},(\mathrm{C} 1122 \mathrm{AAH}) \mathrm{CABA}$

Buenos Aires, Argentina

giselapulitano@gmail.com

epithelial cells out of epithelial context. Cytokeratins and other cytoskeletal proteins in the rest of Malassez of the periodontal ligament. Differentiation 1995; 59:113-126.

12. Tadokoro O, Maeda T, Heyeraas KJ, Vandevska- Radunovic V, Kozawa Y, Hals Kvinnsland I. Merkel-like cells in Malassez epithelium in the periodontal ligament of cats: an immunohistochemical, confocal-laser scanning and immuno electron-microscopic investigation. J Periodont Res 2002;37:456-463.

13. Li S, Ge S, Yang P. Expression of cytokeratins in enamel organ, junctional epithelium and epithelial cell rests of Malassez. J Periodontal Res 2015;50:846-854.

14. Onishi T, Ooshima T, Sobue S, Tabata MJ, Maeda T, Kurisu $\mathrm{K}$, Wakisaka S. Immunohistochemical localization of calbindin D28k during root formation of rat molar teeth. Cell Tissue Res 1999;297:503-512.

15. Guajardo G, Okamoto Y, Gogen H, Shanfeld JL, Dobeck J, Herring $\mathrm{AH}$, Davidovitch $\mathrm{Z}$. Immunohistochemical localization of epidermal growth factor in cat paradental tissues during tooth movement. Am J Orthod Dentofacial Orthop 2000;118:210-219.

16. Takahashi K, Shimonishi M, Wang R, Watanabe H, Kikuchi M. Epithelial- mesenchymal interactions induce enamel matrix proteins and proteases in the epithelial cells of the rests of Malassez in vitro. Eur J Oral Sci 2012;120:475-483.

17. Haruyama N, Hatakeyama J, Moriyama K, Kulkarni A. Amelogenins: Multi-functional enamel matrix proteins and their binding partners. J Oral Biosci 2011;53:257-266.

18. Zeichner-David M, Chen LS, Hsu Z, Reyna J, Caton J, Bringas P. Amelogenin and ameloblastin show growthfactor like activity in periodontal ligament cells. Eur J Oral Sci 2006;114:244-253. 
19. Kémoun P, Gronthos S, Snead ML, Rue J et al. The role of cell surface markers and enamel matrix derivatives on human periodontal ligament mesenchymal progenitor responses in vitro. Biomaterials 2011; 32:7375-7388. doi: 10.1016/j.biomaterials.2011.06.043.

20. Nishio C, Wazen R, Kuroda S, Moffatt P, Nanci A. Disruption of periodontal integrity induces expression of apin by epithelial cell rests of Malassez. J Periodont Res 2010;45:709-713.

21. Merrilees MJ, Sodek J, Aubin JE. Effects of cells of epithelial rests of Malassez and endothelial cells on synthesis of glycosaminoglycans by periodontal ligament fibroblasts in vitro. Dev Biol 1983;97:146-153.

22. Rincon JC, Xiao Y, Young WG, Bartold PM. Production of osteopontin by cultured porcine epitheliacell rests of Malassez. J Periodont Res 2005;40:417-426.

23. Firth JD, Putnins EE, Larjava H, Uitto VJ. Bacterial matrix metalloproteinase expression by cultured epithelial cells. Infect Immun 1997;65:4931-4936.

24. Uitto VJ, Airola K, Vaalamo M, Johansson N, et al. Collagenase-3 (matrix metalloproteinase- 13) expression is induced in oral mucosal epithelium during chronic inflammation. Am J Pathol 1998;152:1489-1499.

25. Yang Z, Li Y, Ma X, Shen L, Zhao Z, Jin F1. Role of the Epithelial Cell Rests of Malassez in Periodontal Homeostasis and Regeneration - A Review. Curr Stem Cell Res Ther 2015;10:398-404.

26. Xiong J, Gronthos S, Bartold PM. Role of the epithelial cell rests of Malassez in the development, maintenance and regeneration of periodontal ligament tissues. Periodontol 2000 2013;63:217-233.

27. Koshihara T, Matsuzaka K, Sato T, Inoue T. Effect of stretching Force on the Cells of Epithelial Rests of Malassez In Vitro. Int J Dent 2010;2010:458408. doi: 10.1155/2010/458408.

28. Pulitano Manisagian GE, Benedí D, Goya JA, Mandalunis PM. Study of epithelial rests of Malassez in an experimental periodontitis model Acta Odontol Latinoam. 2018;3:131137.

29. Talic NF, Evans CA, Daniel JC, Zaki AE. Proliferation of epithelial rests of Malassez during experimental tooth movement. Am J Orthod Dentofacial Orthop 2003;123:527533.
30. Nuñez FL, Pulitano Manisagian GE, Ubios AM, Mandalunis PM, Bozal CB. Modelo experimental de resorción radicular mediante fuerzas ortodóntica [Abstr.] 2017. URL: http:// www.saio.org.ar/new/descargas/Libro_L_Reunion_ Cientifica_Anual.pdf

31. Kogai H, Nakajima K, Ser-Od T, Al-Wahabi A, Matsuzaka $\mathrm{K}$, Nakagawa T, Inoue T. HSP70 mRNA expression by cells of the epithelial rest of Malassez due to mechanical forces in vitro. BMC Oral Health 2016;16:22. doi: 10.1186/ s12903-016-0181-4.

32. Muraoka R, Nakano K, Matsuda H, Tomoda M et al. A consideration on the role of HSP70 appearing in the periodontal tissue due to experimental orthodontic force. $\mathrm{J}$ Hard Tissue Biol 2011;20:275-282.

33. Wentz FM, Weinmann JP, Schour I. The prevalence, distribution, and morphologic changes of the epithelial remnants in the molar region of the rat. J Dent Res 1950;29:637-646.

34. Reeve CM, Wentz FM. The prevalence, morphology, and distribution of epithelial rests in the human periodontal ligament. Oral Surg Oral Med Oral Pathol 1962;15:785793.

35. Gonçalves JS, Sasso-Cerri E, Cerri PS. Cell death and quantitative reduction of rests of Malassez according to age. J Periodont Res 2008;43:478-481.

36. Sims MR, Leppard PI, Sampson WJ, Dreyer CW. Microvascular luminal volume changes in aged mouse periodontal ligament. J Dent Res 1996;75:1503-1511.

37. Hasegawa N, Kawaguchi H, Ogawa T, Uchida T, Kurihara H. Immunohistochemical characteristics of epithelial cell rests of Malassez during cementum repair. J Periodont Res 2003;38:51-56.

38. Tsunematsu T, Fujiwara N, Yoshida M, Takayama Y et al. Human odontogenic epithelial cells derived from epithelial rests of Malassez possess stem cell properties. Lab Invest 2016; 96:1063-1075. doi: 10.1038/labinvest.2016.85.

39. Miron RJ, Sculean A, Cochran DL, Froum S et al. Twenty years of enamel matrix derivative: the past, the present and the future. J Clin Periodontol. 2016;43:668-683.

40. Nenda MM, Lewicki M, Mandalunis PM. Histomorphometry of the tibia and mandible of healthy female Wistar rats at different stages of growth. Exp Anim. 2016;65:109-116. doi: 10.1538/expanim.15-0069. PMID: 26568145. 